\title{
Informuoto paciento sutikimo
}

principai

\author{
Danielius Serapinas \\ LSMU MA Pulmonologijos ir imunologijos klinika
}

Reikšminiai žodžiai: informuoto paciento sutikimas, gydytojas, konsultavimas.

Santrauka. Gydytojo pareiga informuoti pacientą neatsiejama nuo pareigos gauti informuoto paciento sutikimą, būtiną bet kokioms medicininėms procedūroms ar intervencijoms pradèti. Pagrindiniai reikalavimai informuoto paciento sutikimui yra racionalumas, pakankama ir aiški informacija, laisva valia bei atitikimas teisės aktų numatytus formos reikalavimus. Gauti informuoto paciento sutikimą nẻra absoliutus reikalavimas, nes pacientas turi teisę pareikšti norą nežinoti apie savo sveikatos būklę, gali susiklostyti ir tokios aplinkybès, kai gydytojas neturi galimybės informuoti paciento, o pacientas ar jo atstovas negali duoti sutikimo. Šio straipsnio pagrindiniai tikslai - apibrěžti informuoto paciento sutikimo doktriną ir reikalavimus, keliamus informuoto paciento sutikimui.

\section{IVADAS}

Spartėjanti biomedicinos mokslo pažanga, nauji gydymo būdai ir metodai, kintančios technologijos padeda sveikatos priežiūros paslaugų srityje pasiekti vis geresniu rezultatų. Dèl šios priežasties auga sveikatos priežiūros paslaugų apimtys, todèl jas būtina reguliuoti teisès normomis, garantuojančiomis gerą paslaugu kokybę, įtvirtinančiomis gydytojų ir pacientu teises bei pareigas, gydytoju ir pacientu santykiu pobūdì [1]. Vienas pagrindiniu bioetikos principu nuo Hipokrato laiku primum non nocere, t. y. pirmiausia nepakenkti. Iš to išplaukia žalos nedarymo, geradarystès, pareigos gydyti bei gerbti paciento autonomiją principai, kurie nuo seniausių laikų laikomi medicinos etikos pagrindu. Neretai pasitaiko atvejų, kai, tarkim, su sisteminio gydymo schema sutikęs pacientas po kurio laiko atvyksta nutraukęs gydymą, ir ligai paūmejjus. Kyla klausimas, ar gydytojas viską padarè, kad pacientas tinkamai suprastų ir galetu vykdyti gydytojo duotus gydymo nurodymus. Jei tai buvo padaryta, tada pacientas pats prisiima atsakomybę už gydytojo sudaryto gydymo plano vykdymą. Konsultacija kabine, kurios metu „čia ir dabar" gydytojas visiškai atsakingas už pacientą, trunka vidutiniškai 15-20 minučių, kitą paros dali gydytojas negali kontroliuoti paciento ir tuo pačiu būti atsakingas už tai, kaip jis laikosi paskirto gydymo re- žimo. Paciento informavimas, kaip etinis reikalavimas, yra neatsiejamas nuo pagarbos pacientui bei jo autonomijai. Pagarbos paciento autonomijai principas garantuoja penkias labai svarbias pacientų teises: teisę i pasirinkimą, teisę i asmens privatumą, teisę i informaciją, teisę i konfidencialumą bei teisę nebūti diskriminuojamam [2]. Gydytojo pareiga informuoti pacienta yra neatsiejama nuo pareigos gauti informuoto paciento sutikimą, kuris būtinas bet kokioms medicininèms procedūroms ar intervencijoms pradèti. Bet kokie gydytojo veiksmai be informuoto paciento laisvo sutikimo yra neteisèti, išskyrus teisès aktuose numatytus išimtinius atvejus. Straipsnyje aptariama informuoto paciento sutikimo doktrina, reikalavimai, keliami informuoto paciento sutikimo taikymui, Lietuvos Respublikos teisès aktai, reglamentuojantys informuoto paciento sutikimą, ir teismu praktika Lietuvoje.

\section{INFORMUOTO PACIENTO SUTIKIMO DOKTRINA}

Sveikatos priežiūros srityje vis labiau isitvirtina gydytojo ir paciento santykiai, paremti abipusiu bendradarbiavimu, atsisakant anksčiau vyravusio paternalizmo principo, kai visus sprendimus priimdavo gydytojas. Tokị pokytị lemia isitvirtinantis autonomijos principas, kuris skatina žmogaus gebèjimą savarankiškai pasirinkti ir atlikti veiksmus.
Pagarba paciento autonomijai medicinos etikoje išreiškiama informuoto paciento laisvo sutikimo reikalavimu [3]. Priešingai paternalizmui, autonomija iš esmès reiškia tai, kad subjektas yra geriausias savo interesu atstovas, todèl pats gali spręsti, kas jam yra svarbu, kokioms vertybėms teikia pirmenybę, vadovaujasi savo laisva valia, be išorinès ittakos ir jokios prievartos.

Autonomija sudaro trys elementai:

- saviraiška atliekant veiksmus;

- laisvé;

- racionalumas.

Saviraiška atliekant veiksmus parodo žmogaus vertybes, norus bei troškimus ir galimybę juos igyvendinti. Laisvè autonomijoje yra bene svarbiausias elementas, kuri sudaro asmens vidinė ir išorinè laisvè, reiškianti, kad priimdamas sprendimus asmuo nèra veikiamas jokios pašalinès itakos ar prievartos. Tai sąmoningas ir savanoriškas paciento apsisprendimas, leidžiantis arba neleidžiantis gydytojui imtis atitinkamu veiksmų. Laisvas sutikimas yra niekaip nesuderinamas su prievarta, spaudimu, tiesiogiai ar netiesiogiai bandant paveikti paciento apsisprendimą. Visgi gydytojo nuomonè yra labai svarbus veiksnys, padedantis pacientui priimti sprendimą, tad gydytojo ižvalgos ir profesionalumas gali labai prisidèti prie paciento pasirinkimo. Racionalumas siejamas su asmens gebejjimu suprasti jam pateiktą informaciją ir atitinkamai $i$ ją reaguoti, 
nustatyti, kas teisinga, suprasti esamą situaciją bei numatyti būsimas pasekmes. Racionalumui būdingas sąmoningas ir tikslingas paciento elgesys [4].

Be visų šiu autonomijos elementų, būtina paminèti paciento kompetenciją. Tik kompetentingas pacientas gali priimti racionalius sprendimus. $\mathrm{Pa}$ ciento kompetencijai galima priskirti šiuos formalius gebejjimus:

- gebejjimas formuluoti deramus tikslus, ypač tolesnius ateities planus; - gebejjimas nustatyti tụ tikslų loginę seką;

- gebèjimas apibrèžti, kodèl siekiama pasirinktų tikslų;

- gebejjimas veiksmingai vykdyti ateities planus;

- gebejjimas atsisakyti arba keisti tu tikslų pobūdị, jei gaunami siekiu neatitinkantys rezultatai [2].

Informuoto paciento sutikimas gali būti suprantamas kaip procesas, kurio metu asmuo, disponuodamas visa informacija ir būdamas laisvas apsispręsti, priima savo sprendimą dèl gydymo [5]. Informuoto paciento sutikimas yra bendradarbiavimo tarp gydytojo ir paciento rezultatas, turintis itakos galutiniam sprendimui ir gydymo taikymui. I informuoto paciento sutikimą reikia žvelgti kaip i procesą, kuris apima gydytojo ir paciento tarpusavio supratimą bei keitimąsi informacija gerbiant paciento autonomiją.

Svarbu paminèti, jog informuoto paciento sutikimas dažnai klaidingai painiojamas su sutikimo forma. Iš tikrųjų sutikimas yra informuoto paciento pritarimas tam tikrai procedūrai ar medicininei intervencijai gavus tinkamą, išsamią, nedviprasmišką informaciją iš gydytojo apie diagnozę, gydymo būdus, potencialią riziką, naudą bei galimas alternatyvas. Sutikimo forma yra tik vienas iš informuoto paciento sutikimo proceso dokumentų, nes sutikimas išreiškiamas ne tik raštu, bet ir žodžiu [6].

Informuoto paciento sutikimas yra teisinė priemonė apsaugoti paciento teises bei gauti visą informaciją apie ligos diagnozę, gydymo galimybes, alternatyvius gydymo būdus, numatomus rezultatus ar pasekmes, jei jis sutinka ar nesutinka gydytis. Gauti informuoto paciento sutikimą nèra absoliutus reikalavimas, mat jis turi teisę nežinoti savo ligos diagnozès. Lietuvos Respublikos teisès aktuose, kurie aptariami kitame šio darbo poskyryje, numatytos išimtys, kada gydytojas, veikdamas paciento naudai, gali nepranešti jam apie jo būklę, jei tai sukeltų didesnès žalos sveikatai. Gydytojas, veikdamas teikiant būtinąją pagalbą, jei pacientas yra be sąmonès ar kitos būklès, kai nesugeba duoti sutikimo dèl savo gydymo, gali veikti ir gelbèti jo gyvybę be sutikimo.

Informuoto paciento sutikimas apsauga ne tik pacientui, bet ir sveikatos priežiūros specialistui, kuris, suteikęs išsamią informaciją apie gydymą ir jo galimybes bei alternatyvas, nusiima subjektyvių sprendimų naštą. Atsakomybé turi tekti ir gydytojui, ir pacientui. Sveikatos priežiūros specialistas, gavęs sutikimą bus tikras, kad pacientui gydymas ar kita intervencija yra priimtina ir jis sutinka, kad ji būtu atlikta, o pacientas, gavęs informaciją, bus ramus, jog be jo žinios nebus atliekami jokie veiksmai, dèl kurių jis nedavè sutikimo ar apie kuriuos jis nebuvo informuotas.

Informuoto paciento sutikimas, galima teigti, kartu yra ir etinis reikalavimas, kilęs iš pagrindinių medicinos etikos principų. Gydytojai, duodami Hipokrato priesaiką, prisiima pareigą gerbti pacientą ir jo autonomiją, nedaryti žalos, laikytis konfidencialumo bei kitu principu. Vis dèlto reikia pabrèžti, kad tai ne tik etiné, bet ir teisine doktrina, ittvirtinta teisès aktais pagarbos paciento autonomijai pagrindu.

\section{REIKALAVIMAI INFORMUOTO PACIENTO SUTIKIMUI}

Ne kiekvienas paciento sprendimas dèl gydymo gali būti laikomas laisvu informuoto paciento sutikimu, nes toks sutikimas turi atitikti nustatytus reikalavimus. Lietuvoje bendruosius reikalavimus, keliamus informuoto paciento sutikimui nustato $1996 \mathrm{~m}$. Lietuvos Respublikos Pacientų teisių ir žalos sveikatai atlyginimo istatymo (toliau - LR PTSŽİ) III skyrius „Informuoto paciento sutikimas". İstatymu ịtvirtinta, jog paciento sutikimas turi būti pagrịstas informacija ir tinkamas. Šios sąlygos yra būtinos asmens valiai išreikšti dèl tam tikros procedūros ar gydymo. Jei nèra bent vienos iš šių sąlygų, paciento sutikimas laikomas netinkamu ir neturi teisinès reikšmès. Sutikimas laikomas pagrịstas informacija ir tinkamas, kai atitinka šias pagrindines sąlygas:

1. Yra duotas asmens, galinčio tinkamai išreikšti savo valią;

2. Yra duotas, gavus pakankamą ir aiškią informaciją;

3. Yra duotas paciento (jo atstovo) laisva valia;

4. Atitinka teisès aktų nustatytus formos reikalavimus [7].
Sutikimo formos reikalavimai yra nustatyti 2010 m. Lietuvos Respublikos sveikatos apsaugos ministro issakymu „Dèl sutikimo dèl sveikatos priežiūros paslaugu teikimo formos reikalavimu aprašo patvirtinimo“. Jame aprašyta, kokia informacija sveikatos priežiūros istaigoje specialistų turi būti pateikta, kad paciento sutikimas būtų laikomas tinkamu ir pagristu informacija, t. y.: - informacija apie toje sveikatos priežiūros įstaigoje teikiamų mokamų, iš dalies mokamų paslaugų kainas bei galimybes jomis pasinaudoti;

- informacija apie nemokamas paslaugas bei galimybes jomis pasinaudoti;

- informacija apie siuntimo i kitas sveikatos priežiūros ịstaigas tvarką;

- informacija apie ístaigos vidaus tvarkos taisykles;

- informacija apie sveikatos priežiūros paslaugas teikiančiu specialistų profesinę kvalifikaciją, taip pat galimybę rinktis sveikatos priežiūros specialistą;

- informacija apie paciento pareigą bendradarbiauti su sveikatos priežiūros paslaugas paskyrusiu ir (ar) teikiančiu sveikatos priežiūros specialistu, vykdyti jo paskyrimus ir nurodymus, pranešti apie bet kokius nukrypimus nuo paskyrimų [8]. Taigi pacientas turi teisę gauti informaciją ne tik išimtinai susijusią su jo sveikatos būkle, ligos diagnoze, rizikomis ar galimomis komplikacijomis, bet ir visą informaciją apie sveikatos priežiūros įstaigoje teikiamas paslaugas, jų kainas bei galimybę jomis pasinaudoti. Visa tai reglamentuoja LR PTSŽI 5 str.

Labai svarbus ir pačios informacijos pateikimo būdas. Gydytojas, atsižvelgdamas i paciento amžių, sveikatos būklę, patirtị, išsilavinimą bei kitus veiksnius, galinčius lemti asmens suvokimą, privalo suteikti visą būtiną informaciją, paaiškinti medicinos terminus, kuriụ pacientai nesupranta, ypač susidūrę su jais pirmą kartą. Informacijos pateikimo būdai gali būti ịvairūs: vaizdinès projekcijos, žmogaus kūno dalių maketai, iliustruoti lankstinukai, knygos ir pan., kad pacientas kuo geriau suprastu jam siūlomą atilikti procedūrą. Tyrimais nustatyta, kad atliekant operacijas ar net tokias procedūras kaip bronchoskopija kyla mažiau komplikacijų, jei pacientui kuo vaizdžiau ir aiškiau apie ją būna paaiškinta iš amksto.

Galimos ir tokios situacijos, kai gydytojui sunku ịvertinti, ar pacientas viską suprato teisingai ir tinkamai. 
Tam reikalingas atgalinis ryšys, kuriuo pacientas parodo, ar tikrai suprato jam pateiktą informaciją. Sutikimas gali būti išreiškiamas žodžiu, raštu arba konkliudentiniais veiksmais. Viskas priklauso nuo to, kokio sudetingumo procedūra ar intervencija bus atliekama. Raštiškas sutikimas reikalingas sudètingesnèms procedūroms ar intervencijoms atlikti: kaip antai operacijoms, įvairiems tyrimams ar kitoms invazinèms procedūroms. Konkliudentiniais veiksmais galima laikyti paciento atẻjimą ì sveikatos priežiūros ìstaigą darant prielaidą, kad jis sutinka būti apžiūrètas, ìvertinta jo sveikatos būklè, paskirti tyrimai ar gydymo procedūros, pvz.: pamatuotas kraujo spaudimas, paklausytas širdies ritmas, paimta kraujo tyrimui ir pan. Tai reglamentuoja 1996 m. LR PTSŽI 16 str. 1 dalis. Svarbu pabrèžti, kad sveikatos priežiūros ịstaiga turi užtikrinti, jog visa informacija bus pateikta paciento lankymosi metu, o tos įstaigos darbuotojai atsakys i visus iškilusius klausimus.

1996 m. LR PTSŽI 17 str. įtvirtinta paciento sutikimo rašytiné forma. Šis reikalavimas taikomas konkrečioms chirurginems operacijoms, invazinèms ir intervencinèms procedūroms atlikti. Kad sutikimas būtu laikomas tinkamu, pacientui privalo būti paaiškinta operacijos ar procedūros esmè, juc alternatyvos, pobūdis, tikslai, žinomos ir galimos komplikacijos, pasekmès atsisakius gydymo bei kitos aplinkybès, kurios gali turèti itakos paciento apsisprendimui. Visa ši informacija turi būti pateikta atsižvelgiant ì paciento amžių, sveikatos būklę jam suprantama forma. Rašytinès formos paciento sutikimas akcentuojamas ir Lietuvos Respublikos teismu praktikoje, kuri aptariama kitame šios darbo poskyryje.

Reikètu pabrèžti, jog paciento informavimas nèra tik gydytojo prievolè. It sveikatos priežiūros įstaigą kreipęsis asmuo turi ir pats rodyti iniciatyvą išsiaiškinti tai, ko jis nesuprato ar kas jam liko neaišku iš gydytojo pateiktos informacijos. Jei pacientas neužduoda klausimų, tai dar nereiškia, jog jis tikrai viską suprato. Gydytojas privalo isitikinti, kad jo pateikta informacija buvo aiški ir suprantama, o pacientui neliko klausimų apie būsimą procedūrą, jos alternatyvas ar pasekmes.

Dar vienas ir labai svarbus reikalavimas - informacijos patikimumas. Tai reiškia, jog informacija, teikiama pacientui, turi atitikti naujausias medicinos ir mokslo tendencijas, pasieki- mus bei patikrintą ilgalaikę medicinos praktiką. Gydytojas turi pateikti tik tą informaciją, kuri yra reikalinga konkrečiu atveju, ji neturi būti perteklinè ir sudetinga. Informacijos pateikimo detalumas ir apimtis priklauso nuo procedūros sudètingumo, rizikos bei galimų šalutinių poveikių. Kuo didesnè rizika sveikatai, kuo platesnes žmogaus gyvenimo sferas apima galima žala, tuo labiau būtina apie ją pranešti, nes toks informavimas lems asmens motyvuota sprendimą [5]. Taigi, kai gydytojas pacientui aiškins, pavyzdžiui, apie širdies operacijos atlikimą bei riziką ir apgamo šalinimo procedūrą, informacijos kiekis ir sudètingumas bus skirtingas.

Lietuvos Respublikos Konstitucijos [9] 21 straipsnyje yra itvirtintas informuoto asmens sutikimo pagrindas: žmogaus asmuo yra neliečiamas ir be jo žinios ir laisvo sutikimo negali būti atliekami moksliniai ar medicinos bandymai. Toliau pateikiami dokumentai, kurie detaliau reglamentuoja informuoto paciento sutikimą.

$1994 \mathrm{~m}$. Sveikatos sistemos istatymas [11]. Šio ístatymo keliuose straipsniuose užsimenama apie informuoto paciento sutikimo reikalavimą. 1) 15 str. „Sveikatinimo veiklos būtinosios sąlygos" ịtvirtinta, jog viena iš būtinųjų sveikatinimo sąlygu yra asmens sutikimas gauti sveikatos priežiūros paslaugas, išskyrus ịstatyme numatytus atvejus, kai tokios paslaugos gali būti suteikiamos ir be jo sutikimo. 2) 20 str. „Diagnostikos ir gydymo priemonių taikymo ypatumai“ įtvirtinta, jog sveikatos priežiūros specialistai gali panaudoti naujus, moksliškai pagristus, bet dar nustatyta tvarka neiregistruotus vaistus, neaprobuotus profilaktikos, diagnostikos ir gydymo metodus, medicinos aparatūrą ir instrumentus tik stengdamiesi pacientą išgydyti, išgelbèti ar pratęsti jo gyvybę. Tokiu atveju sveikatos priežiūros specialistai privalo gauti paciento sutikimą, jei pacientas yra nesąmoningas ar nepilnametis - jo tèvų, artimųjų, globejju ar atstovo sutikimą. Tam taip pat reikalingas sveikatos priežiūros įstaigos medicinos etikos komisijos sutikimas. Tokiam asmens, jo atstovu ar medicinos etikos komisijos sutikimui yra keliamas rašytinès formos reikalavimas. 3) 21 str. „Žmogaus kraujo ir jo produktu transfuzija“ taip pat numato, jog kraujo iš donoro gali būti paimta tik jo laisva valia ir sutikimu.
1996 m. Pacientu teisiu ir žalos sveikatai atlyginimo istatymas [7]. $2010 \mathrm{~m}$. kovo $1 \mathrm{~d}$. ìsigaliojusioje naujoje istatymo redakcijoje daug dèmesio skiriama paciento informavimui bei sutikimui. Prieš teikiant bet kokias sveikatos priežiūros paslaugas, išskyrus tam tikrus atvejus, numatytus įstatyme, sveikatos priežiūros specialistai turi gauti paciento sutikimą. Labai svarbus istatymo 17 straipsnis, kuriame yra itvirtinti reikalavimai informuoto paciento sutikimui. Pacientams, kuriems suejjo 16 metų, sveikatos priežiūros paslaugos teikiamos tik gavus jo sutikimą, išreikštą laisva valia, po išsamios ir aiškios informacijos suteikimo. Toks sutikimas atitinka teisès aktu keliamus reikalavimus, išskyrus tam tikrus atvejus, kai pacientas arba jo atstovas tokio sutikimo duoti negali (pvz.: teikiant būtinąsias medicinos pagalbos paslaugas, taip pat atliekant priverstinį (būtinąji) paciento guldymą $\mathfrak{i}$ stacionarinę sveikatos priežiūros įstaigą).

$2000 \mathrm{~m}$. Biomedicininiu tyrimu etikos istatymas [12]. Pagrindinès šio ìstatymo sąvokos apibrèžia, kas yra informuoto asmens sutikimas: „aiškus, sąmoningai duotas rašytinis tiriamojo sutikimas dalyvauti biomedicininiame tyrime“. Vienas pagrindiniu principu ir reikalavimų, ittvirtintu istatymo 4 str., jog biomedicininiam tyrimui atlikti būtinas „savanoriškas tiriamojo asmens sutikimas“. Tai pabrèžiama ir kituose šio istatymo straipsniuose. 8 str. „Asmens sutikimas“ detalizuoja informuoto asmens sutikimo reikalavimus. Šis straipsnis įtvirtina rašytinès formos sutikimo reikalavimą. Prieš duodamas sutikimą, asmuo suprantama forma pasirašytinai supažindinamas su biomedicininio tyrimo tikslu, planu, taikomai metodais, ir kt.

1995 m. Psichikos sveikatos priežiūros istatymas [13]. Šio i̇statymo 15 straipsnis detaliai nurodo, jog psichiatras privalo informuoti pacientą jam suprantama forma, paaiškindamas specialius terminus apie jo sveikatos būklę, ligos diagnozę, galimus gydymo būdus, gydymo prognozę bei kitas aplinkybes, kurios gali turèti ittakos jo apsisprendimui sutikti gydytis ar atsisakyti siūlomo gydymo, taip pat apie pasekmes, jei tokio gydymo atsisakytu. Šis straipsnis taip pat numato ribojimus, kada pacientui informacija yra neteikiama tol, kol išnyksta pavojus jam bei aplinkiniams, o informuojamas jo atstovas. 
Istatyme akcentuojama, jog be paciento sutikimo gydymas negali būti skiriamas, išskyrus priverstinio hospitalizavimo atvejus, norint išgelbèti paciento gyvybę ir kai jam gresia realus pavojus.

\section{AT VEJAI, KAI PACIENTO NEINFORMAVIMAS YRA PATEISINAMAS}

Kiekvienas pacientas, gebantis savarankiškai priimti sprendimus ir veikdamas autonomiškai gali ir turi teisę būti neinformuotas. Tokia jo valia privalo būti aiškiai išreikšta, bet jokiu būdu ne numanoma. Labai svarbu, kad pacientas suvoktų neinformavimo pasekmes ir prisiimtu už tai atsakomybę. LR PTSŽI 6 str. yra numatyta asmens teisè nežinoti: „informacija apie paciento sveikatos būklę, ligos diagnozę, sveikatos priežiūros ịstaigoje taikomus ar gydytojui žinomus kitus gydymo ar tyrimo būdus, galimą riziką, komplikacijas, šalutini poveikį, gydymo prognozę negali būti pacientui pateikiama prieš jo valią. Atsisakymą gauti informaciją pacientas turi aiškiai išreikšti ir patvirtinti parašu [7]“. Taigi šiuo atveju pacientas, išreikšdamas savo valią nežinoti, privalo būti tinkamai informuotas apie tokio atsisakymo pasekmes. Šio ịstatymo 2 dalyje itvirtinta, kad tokie apribojimai yra netaikomi, kai dèl paciento atsisakymo gauti informaciją gali atsirasti žalingų padarinių pacientui ar kitiems asmenims. Tokia išimtis numatyta ir Lietuvos Respublikos Civilinio kodekso 6.728 str. 2 dalyje: „informacijos pateikimo pacientui apribojimai netaikomi, kai dèl paciento nenoro (atsisakymo) gauti informaciją gali atsirasti žalingų pasekmių pacientui ar kitiems asmenims [10]“. Taigi gydytojas, atsižvelgdamas ì paciento situaciją ir būklę, turi nuspręsti, kaip jam tinkamiau pasielgti. Tačiau praktikoje gali būti sunku numatyti ir îvertinti paciento elgesi bei veiksmus. Gydytojas atsiduria situacijoje, kai turi pasirinkti - gydytojo pareigą informuoti ar paciento teisę nežinoti.

Asmens valios pareiškimui nežinoti taip pat galioja jau anksčiau minètos trys sąlygos: visapusiška ir išsami informacija, sutikimas duotas laisva valia ir sprendimas priimtas kompetentingo paciento. Jis galios tik tuo atveju, jei bus pasirašytas paciento, gerai informuoto apie pasekmes, jis bus niekieno neveikiamas ir supras savo veiksmų reikšmę. Svarbus asmens kompetencijos klausimas, nes tik gerai informuotas ir racionaliai vertinantis situaciją pacientas gali priimti teisingus sprendimus. Geram medicinos specialistui turètų būti žinoma: jeigu pacientas neklausinejja, tai nereiškia, kad jis nenori sužinoti, kas ir kaip ketinama daryti [2]. Taigi viena pagrindinių sąlygų yra aiškiai išreikšta valia, ji negali būti numanoma.

Gydytojo pareiga informuoti pacientą ir gauti jo sutikimą nèra absoliuti, mat gali susiklostyti tokios aplinkybės, kai gydytojas neturi galimybès informuoti paciento, o pacientas ar jo atstovai negali duoti sutikimo. Lietuvos teisès aktuose numatyti išimtiniai atvejai, kada paciento (jo atstovo) sutikimo dèl procedūros nereikalaujama. Sutikimo nereikalaujama teikiant būtinąsias medicinos pagalbos paslaugas, kai pacientas negali savo valios išreikšti pats (dèl amžiaus ar sveikatos būklès) ir nèra galimybiu gauti paciento atstovo (jei toks yra) sutikimo taip greitai, kaip tai būtina; taip pat guldant pacientą i stacionarinę sveikatos priežiūros ìstaigą, kad būtų apsaugot visuomenès interesai. Priverstinị (būtinąji ) paciento guldymą $\mathfrak{i}$ stacionarinę sveikatos priežiūros įstaigą be paciento sutikimo reglamentuoja 1996 m. Žmonių užkrečiamųjų ligu profilaktikos ir kontrolès istatymas [14], 1995 m. Psichikos sveikatos istatymas [13]. Šiuo atveju paciento sutikimas yra numanomas, t. y. daroma prielaida, jog esant rimtai grèsmei paciento gyvybei jis sutiktų būti gydomas. Tam tikrai atvejais, pavyzdžiui, kai yra teikiamos būtinosios medicinos paslaugos, pacientas iš anksto gali būti pareiškęs nesutikimą, kad jam būtų taikomas gydymas, nors gydymo netaikymas būtu pavojingas jo gyvybei. LR PTSŽI 18 str. numato išimtis dèl nepilnamečiuc pacientu nuo 16 metų sveikatos priežiūros paslaugų taikymo. Jei sveikatos priežiūros paslauga turi būti teikiama pacientui nuo 16 metų, kuris negali būti laikomas gebančiu protingai vertinti savo interesuc, ir nèra jo atstovu bei negalima su jais greitai susisiekti, tokiais atvejais sprendimus priima sveikatos priežiūrą teikiantis gydytojas, o prireikus gydytojų konsiliumas. Tokios pat sąlygos numatytos ir nepilnamečiams iki 16 metų amžiaus.

Lietuvos Respublikos Civilinio kodekso 6.727 straipsnio 2 dalyje numatyta išimtis, kad gydytojas turi teisę nepranešti pacientui apie jo sveikatos būklę, diagnozę, gydymo prognozes bei kitas aplinkybes, kai žinia aiškiai sąlygotu pacientui rimtą žalą (pakenktų paciento sveikatai ar net sukeltų pavojų jo gyvybei). Gydytojo sprendimu informacija suteikiama paciento atstovui ir tai prilygsta paciento informavimui, tačiau informacija pacientui privalo būti suteikta iš karto, kai išnyksta pavojus, kad toks pranešimas gali sukelti rimtas pasekmes paciento sveikatai.

Sprendimas pranešti ar nepranešti pacientui užkrauna gydytojui sunkią naštą: jo subjektyvi nuomonè gali nesutapti su paciento nuomone, ir tai vienaip ar kitaip gali paveikti paciento sveikatos būklę. Visais atvejais sunku numatyti asmens psichologinę būklę ir pasirengimą priimti tam tikrą informaciją, susijusią su ligos diagnoze. Tikimybé, kad gydytojas gali suklysti, yra labai didelè, tad norit priimti geriausią sprendimą tam tikroje situacijoje gydytojas turètu konsultuotis su paciento artimaisiais, jei tik pacientas nèra pareiškęs valios, jog niekas negalètu susipažinti su jo medicinos dokumentais. Pacientas turi teisę nurodyti asmenis, kuriems konfidenciali informacija negali būti teikiama. Tai reglamentuoja 1996 m. PTSŽİ. Šiame isstatyme ittvirtinta, jog „asmenims, tiesiogiai dalyvaujantiems gydant ar slaugant pacientą, atliekantiems paciento sveikatos ekspertizę, be paciento sutikimo konfidenciali informacija gali būti suteikiama tais atvejais ir tiek, kiek tai būtina paciento interesams apsaugoti [7]“. Tad galima daryti išvadą, jog gydytojas turi teisę konsultuotis su kolegomis dèl sprendimo pranešti ar nepranešti pacientui apie jo sveikatos būklę, o tai padidina tikimybę padaryti kuo mažiau žalos pacientui.

\section{PRINCIPALS OF PATIENT INFORMED CONSENT}

DANIELIUS SERAPINAS LUHS MA DEPARTMENT OF PULMONOLOGY AND IMMUNOLOGY

Keywords: informed consent, doctor, consultation. Summary. The obligation of doctors to inform patients is inseparable from the requirement to receive informed consent. The two parts are mandatory for any medical procedures and interventions. The main requirements for the informed consent include rationality, sufficient and clear information, free will and the form of consent conforming to the legal acts. However, the informed consent is not an absolute requirement as the patient has a right to remain uninformed. Additionally, under certain circumstances it might be impossible to inform patients or to receive consent from patients or their duly authorised representatives. The objectives of the article is to frame the concept and the requirements for informed consent. 